\title{
ANALISIS PENERAPAN PROBLEM BASED LEARNING (PBL) UNTUK MENINGKATKAN PEMAHAMAN KONSEP PADA PERKULIAHAN KIMIA ANALITIK
}

\section{ANALYSIS OF THE APPLICATION OF PROBLEM BASED LEARNING (PBL) TO IMPROVE CONCEPT UNDERSTANDING IN ANALYTICAL CHEMISTRY LECTURE}

\author{
Muti'ah \\ Program Studi Pendidikan Kimia FKIP Universitas Mataram, Mataram, Indonesia \\ Email: mutiah@unram.ac.id
}

Diterima: 14 Februari 2021. Disetujui: 19 Mei 2021. Dipublikasikan: 2 Juni 2021

\begin{abstract}
Abstrak: Kajian matakuliah Kimia Analitik terkait dengan permasalahan nyata, yaitu menentukan apa dan berapa. Oleh sebab itu problem-based learning PBL merupakan pilihan yang tepat sebagai pendekatan dalam perkuliahan. Artikel ini mendiskusikan secara konseptual mengenai: perlunya PBL dalam perkuliahan Kimia Analitik, mekanisme penempatan dalam silabus, model perkuliahan, sistem penilaian dan keterbatasan penerapan PBL dalam perkuliahan. Secara teknis pelaksanaan PBL dalam perkuliahan Kimia Analitik dilakukan di minggu terakhir perkuliahan. Model perkuliahan mencakup tujuh tahap, yaitu identifikasi masalah, perkuliahan awal, pencarian literatur, tutorial, demonstrasi, eksperimen, dan diakhiri dengan perkuliahan akhir. Sitem penilaian mencakup: tes tertulis, laporan tertulis, unjuk kerja, sikap, dan komunikasi lisan. Beberapa keterbatasan penerapan PBL dalam perkuliahan Kimia Analitik adalah alokasi waktu, laboratorium, dan kemampuan dosen dalam menerapkan metode analisis kimia.
\end{abstract}

Kata Kunci: Problem-Based Learning, Kimia Analitik, model perkulianan, dan sistem penilaian

\begin{abstract}
Analytical Chemistry subject is related to real problems, namely determining what and how much. Therefore, PBL problem-based learning is the right choice as an approach in lectures. This article discusses conceptually: the need for PBL in Analytical Chemistry courses, the placement mechanism in the syllabus, learning models, assessment systems, and the limitations of implementing PBL in lectures. Technically, the implementation of PBL in Analytical Chemistry lectures is carried out in the last week of the lecture. The lecture model includes seven stages: problem identification, initial lectures, literature searches, tutorials, demonstrations, experiments, and the final lecture. The assessment system includes written tests, written reports, performance, attitudes, and oral communication. Some of the limitations of applying PBL in Analytical Chemistry courses are the allocation of time, laboratory, and the ability of lecturers to apply chemical analysis methods.
\end{abstract}

Keywords: Problem-Based Learning, Analytical Chemistry, lecture models, and assessment systems

\section{PENDAHULUAN}

Esensi kurikulum 2013 menegaskan bahwa kompetensi peserta didik tidak hanya dapat memahami pengetahuan $X$, tetapi apa yang dapat dilakukan dengan pengetahuan $\mathrm{X}$ tersebut. Terkait dengan hal tersebut kimia analitik merupakan bagian dari ilmu kimia yang mengkaji zat tentang cara menentukan apa? dan berapa jumlahnya. Oleh sebab itu kompetensi yang diharapkan dari perkuliahan Kimia Analitik tidak hanya pemahaman terhadap konsep sains, tetapi dapat mengkaitkan antara konsep, proses, dan nilai sain untuk memecahkan permasalahan yang berkembang dalam kehidupan sehari-hari. Untuk itu diperlukan suatu pendekatan/strategi pembelajaran yang dapat mencapai tujuan tersebut. Pembelajaran hanya dilakukan dengan metode konvensioanal maka tujuan tersebut sulit tercapai [1].

Berdasarkan kajian literatur yang ditemukan, penerapan pembelajaran berbasis masalah/problem-based learning (PBL) merupakan strategi yang tepat untuk mencapai kompetensi yang diharapkan. Hal ini terkait dengan sifat strategi pembelajaran yang mengkaitkan dunia nyata dan kegiatan berpusat pada siswa, sehingga hasilnya lebih baik dibandingkan dengan pembelajaran konvensional [2-3]. Potter et al., [4] juga menyatakan bahwa dengan PBL seorang siswa terlibat aktif dalam pembelajaran dalam upaya mengembangkan dan menguji hipotesis, sehingga dapat menyelesaikan masalah dengan benar. Dalam hal ini siswa tidak cukup mengingat tentang pengetahuan tetapi bisa melakukan sesuatu dengan pengetahuan tersebut. Melalui PBL siswa juga dapat mengembangkan strategi pemecahan masalah, memperoleh pengetahuan baru, membuat evaluasi, dan prediksi terhadap suatu informasi [5].

Terkait dengan esensi matakuliah kimia analitik, maka penerapan strategi PBL merupakan pilihan yang tepat. Alasan pertama, Kimia Analitik banyak terkait dengan bidang ilmu terapan, misalnya forensik, farmasi, ilmu lingkungan, pangan dan industri kimia [6]. Ke 
dua, ruang lingkup kajian kimia analitik terkait dengan pemasalahan nyata dan bersifat kompleks. Apabila perkuliahan kimia analitik dilakukan dengan metode konvensional, maka mahasiswa tidak dapat menerapkan metode analisis, cara menganalisis data, serta cara melaporkan hasil kerjanya [7].

Berdasarkan hal tersebut di atas, agar strategi PBL dapat diterapkan dengan baik dalam perkuliahan Kimia Analitik, maka diperlukan landasan konseptual yang perlu kaji sebagai berikut:

(1) Mengapa pendekatan PBL diperlukan dalam perkuliahan kimia analitik?

(2) Jika PBL diperlukan dalam perkuliahan Kimia Analitik, bagaimana mekanisme pelaksanaannya?

(3) Jika secara kurikulum PBL dapat dilaksanakan, bagaimana teknik/aplikasinya dalam perkuliahannya?

(4) Jika secara teknik PBL dapat dilaksanakan dalam perkuliahan Kimia Analitik, adakah hambatan yang mungkin terjadi?

Tujuan dari penulisan artikel ini adalah menemukan landasan konseptual untuk penerapan pembelajaran berbasis masalah/Problem-based Learning (PBL) dalam perkuliahan kimia analitik, sehingga pada akhirnya akan diperoleh hasil pembelajaran yang berkualitas.

\section{Pedekatan Problem Based Learning (PBL)}

PBL pertama kali didirikan oleh Howard Barrows ditahun 1960 sebagai bagian dari pendidikan dokter di sekolah kedokteran (HmeloSilver dan Barrows [8]. Problem Based Learning adalah pembelajaran yang didorong oleh adanya masalah, bukan oleh konsep abstrak. Dalam hal ini masalah dapat ditemukan dalam kehidupan nyata, dan siswa tidak hanya harus memecahkan masalah, tetapi mereka juga harus menemukan informasi dan alat serta bahan yang dibutuhkan [6].

Akınoglu dan Tandogan [9] mendefinisikan bahwa PBL adalah strategi pembelajaran dimana sebuah masalah diberikan kepada sekelompok siswa selanjutnya siswa dituntut untuk menyelesaikannya. Dalam hal ini siswa mendiskusikan setiap masalah, mencari literatur terkait dengan masalah tersebut dan mencari informasi pengetetahuan baru guna memecahkan masalah tersebut. Selanjutnya Gallagher, et al [10]. Chin dan Chia [11] menyatakan bahwa dalam pendekatan PBL siswa dijadikan fokus dalam proses pembelajaran, dimana beberapa siswa dalam kelompoknya (5-7 orang) melakukan kerja sama untuk memecahkan masalah yang diberikan oleh seorang guru dan berdiskusi untuk saling tukar pengetahuan. Hasil diskusi tersebut dapat dijadukan dasar perumusan hipotesis, dan mensintesis untuk memecahkan masalah yang diberikan. Hmelo-Silver [12] menyatakan bahwa faktor yang paling penting dari PBL adalah masalah itu sendiri, kemudian permasalahan tersebut harus kompleks dan terstruktur [13], [14]. Menurut
Akınoglu, dan Tandogan [9] PBL adalah pendekatan pembelajaran menargetkan lima hal sebagaimana tercantum dalam tabel 1 .

Tabel 1. Lima Target Utama dalam PendekatanProblem-based Learning

\begin{aligned} \hline Target Utama pendekatan PBL \\ \hline 1. \\ Menyusun \\ konsep/pengetahuan \\ 2. Mengembangkan teknik \\ penalaran, \\ 3. Strategi efektif untuk \\ pengembangan diri \\ 4. Peningkatan motivasi untuk \\ belajar \\ 5. Menjadi kolaborator yang \\ efektif \end{aligned}

Menyusun konsep/pengetahuan baru dalam PBL diperoleh berdasarkan fakta adanya keterlibatan siswa dalam setiap langkah penentuan permasalahan, mencari informasi dan merekonstruksi informasi menjadi pengetahuan Larive [15]. Hal ini sesuai pendapat Hmelo-Silver [12] bahwa seorang siswa dapat membangun pengetahuan baru ketika mereka dapat menghubungkan pengetahuan yang sudah ada. Mengembangkan teknik penalaran didasarkan oleh fakta adanya interaksi langsung antara permasalahan dengan dunia nyata, maka siswa akan mengembangkan kemampuan untuk memahami masalah, merumuskan dan menganalisis hipotesis dan akhirnya membuat keputusan yang tepat untuk memecahkan masalah [3].

Strategi efektif untuk pengembangan diri, dalam PBL seorang siswa harus memutuskan suatu tindakan untuk mencapai tujuan tersebut. Akhirnya, karena mereka melaksanakan rencana mereka sendiri, maka peserta didik harus mampu memantau dan mengevaluasi apakah tujuan mereka telah tercapai [13]. Peningkatan motivasi untuk belajar: karena siswa merasakan adanya masalah yang relevan dengan yang dipelajari dan diselesaikan secara diskusi terbuka, maka rasa ingin tahu dapat timbul [14]. Menjadi kolaborator yang efektif, hal ini disebabkan dalam proses PBL siswa akan terdorong untuk bekerjasama dan saling membantu untuk mendapatkan pemahaman tentang apa yang mereka pelajari dan relevansinya dengan masalah. Ini adalah kolaborasi yang memungkinkan siswa untuk membangun kemampuan yang diperlukan untuk bertanggung jawab atas pembelajaran mereka sendiri. Hal ini sesuai dengan pendapat HmeloSilver dan Barrows [8] bahwa kolaborasi merupakan hal yang sangat diperlukan bagi siswa, karena mereka selalu akan berada sebagai anggota tim. 
Manfaat utama dari pendekatan PBL adalah merangsang siswa untuk belajar di tingkat tinggi, di mana siswa menganalisis, mensintesis dan tidak sekedar memahami dan menerapkan pengetahuan [4], Bahar [16] menyatakan bahwa pembelajaran berbasis masalah dapat meningkatkan minat dan motivasi. Chin dan Chia [11] menyimpulkan bahwa pendekatan PBL dapat meningkatkan sikap siswa yang lebih positif dalam belajar dibandingkan dengan pendekatan konvensional. Salta dan Tzougraki [13] menemukan bahwa pembelajaran menggunakan strategi PBL memberikan hasil belajar siswa yang lebih tinggi dari pembelajaran konvensional. Sedangkan Akınoğlu dan Tandogan [9]) melaporkan bahwa penggunakan PBL dapat meningkatkan prestasi belajar dan kemampuan psikomotorik. Savery dan Duffy [17] melaporkan bahwa pendekatan PBL menunjukkan adanya peningkatan yang signifikan pada prestasi belajar siswa dibandingkan dengan pembelajaran konvensional.

\section{Silabus Matakuliah Kimia Analitik dan Pendekatan PBL}

Konsep dasar matakuliah Kimia Analitik di Program Studi Pendidikan Kimia FKIP Unram mengacu pada Keputusan Dirjen DIKTI Depdiknas No. 36/DIKTI/KEP/1990 [18]. Alokasi waktu bidang Kimia Analitik sebanyak 11 sks dijabarkan menjadi 3 kelompok, yaitu: Kimia Analitik 1 atau Dasar-dasar Kimia Analitik 4(1), Kimia Analitik 2 atau Pemisahan Analitik 4 (1)) dan Kimia Analitik 3 atau Kimia Analitik Instrumen dengan jumlah sks 3 (1) Matakuliah Kimia Analitik 1 bertujuan agar mahasiswa dapat memahami sifat dan konsep dasar kimia analitik serta mampu menyelesaikan berbagai persoalan dasar kimia analitik. Secara garis besar, maka konsep/topik yang dipelajari dalam matakuliah dasar-dasar kimia analitik tercantum dalam tabel 2 .

Tabel 2. silabus matakuliah Kimia Analitik 1 (3sks)

\begin{tabular}{|c|c|}
\hline Topik yang dipelajari & $\begin{array}{l}\text { Alokasi } \\
\text { waktu }\end{array}$ \\
\hline Analisis kualitatif & 6 jam \\
\hline Tahapan analisis kimia & 5 jam \\
\hline Gravimetri & 3 jam \\
\hline Perhitungan dalam Titrasi & 6 jam \\
\hline Titrasi asam basa & $6 \mathrm{jam}$ \\
\hline Titrasi pengendapan & 3 jam \\
\hline $\begin{array}{l}\text { 7. Titrasi pembentukan } \\
\text { senyawa kompleks }\end{array}$ & $3 \mathrm{jam}$ \\
\hline Titrasi redoks & 6 jam \\
\hline Pengajaran & \\
\hline Based Learnig & 6 jam \\
\hline UTS dan UAS & 4 jam \\
\hline Total & 48 jam \\
\hline
\end{tabular}

Berdasarkan data tabel 2, maka penerapan pendekatan PBL dapat dilaksanakan dalam perkuliahan terakhir dengan alokasi waktu sebanyak
6 jam pertemuan. Penempatan pendekatan PBL pada perkuliahan terakhir didasarkan bahwa dalam pendekatan ini siswa dituntut untuk menggunakan pengetahuan sebelumnya dan mendiskusikannya dengan anggota kelompok [9].

\section{Pendekatan PBL dalam Perkuliahan Kimia Analitik}

Pendekatan problem-based learning PBL dalam perkuliahan Kimia Analitik telah diterapkan di negara-negara Barat, misalnya Thomas Wenzel telah menggunakan PBL untuk mengajarkan kimia analitik yang terkait dengan percobaan di laboratorium ([1] dan [19]. Ken Hughes juga telah menggunakan PBL dalam matakuliah pengatantar kimia analisis [20], dan [21]. Berdasarkan hasil analisis dari artikel yang telah dipublikasikan para peneliti di atas, maka model perkuliahan dengan pendekatan PBL dapat dilihat dalam skema gambar 1 .

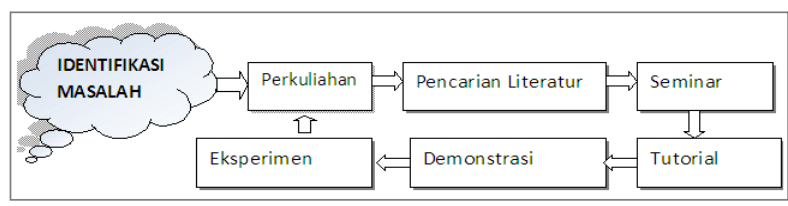

Gambar 1. Skema pendekatan PBL dalam Kimia Analitik

\section{Identifikasi Masalah}

Permasalahan dalam PBL idealnya ditentukan oleh mahasiswa sendiri, namun pada kenyataannya hal tersebut sulit dilakukan. Oleh sebab itu peranan dosen masih sangat diperlukan. Timbulnya masalah dapat dilakukan dengan cara menyajikan video, foto atau kasus yang terkait dengan masalah yang kompleks di lingkungan. Masalah yang kompleks tersebut dapat diuraikan menjadi masalah yang lebih sederhana. Berikut ini contoh permasalahan kompleks yang dijadikan pengakajian dalam PBL di matakuliah Kimia Analitik

Kondisi perairan Sungai Ancar sudah mulai memprihatinkan, terutama di daerah muara (Tanjung Karang). Secara fisik kondisi air sungai tersebut tampak berbeda, misalnya di daerah hulu, Cakranegara, Kekalik, hingga Tanjung Karang.

Di daerah hulu kita masih dapat menemukan berbagai ikan yang hidup di perairan tersebu. Berbeda dengan di daerah Kekalik dan Tanjung Karang, dimana sangat jarang kita temukan ikan di daerah tersebut

Dengan meninjau kualitas air sungai, jelaskan mengapa hal tersebut terjadi ?

Permasalahan tersebut merupakan permasalahan kompleks yang harus dijawab solusinya oleh mahasiswa secara berkelompok 
dengan jumlah $4-5$ orang [11]. Selanjutnya masalah kompleks tersebut diuraikan menjadi masalah sederhana beserta topik yang terkait dengan perkuliahan (tabel 3).

Tabel 3. Daftar permasalahan beserta topik terkait

\begin{tabular}{cll}
\hline No & \multicolumn{1}{c}{ Permasalahan } & \multicolumn{1}{c}{ Topik } \\
\hline 1 & $\begin{array}{l}\text { Berapa kadar total zat } \\
\text { padat, zat padat } \\
\text { terlarut, dan padatan } \\
\text { tersuspensi ? }\end{array}$ & Gravimetri \\
2 & $\begin{array}{l}\text { Berapa nilai pH } \\
\text { perairan sungai } \\
\text { tersebut } ?\end{array}$ & $\begin{array}{l}\text { Kesetimbangan } \\
\text { asam basa }\end{array}$ \\
3 & $\begin{array}{l}\text { Berapa nilai alkalinitas } \\
\text { air sungai tersebut } ?\end{array}$ & Titrasi asam basa \\
4 & $\begin{array}{l}\text { Berapa klorida air } \\
\text { sungai tersebut ? } \\
\text { Berapa kesadahan air } \\
\text { sungai tersebut ? }\end{array}$ & $\begin{array}{l}\text { Titrasi } \\
\text { pengendapan } \\
\text { Titrasi } \\
\text { pembentukan } \\
\text { senyawa kompleks }\end{array}$ \\
6 & $\begin{array}{l}\text { Berapa nilai COD air } \\
\text { sungai tersebut ? }\end{array}$ & Titrasi redoks \\
\hline
\end{tabular}

\section{Perkuliahan}

Dalam tahap ini seorang dosen mengulas kembali tentang teknik analisis gravimetri (penetapan zat padat total, tersuspensi, dan terlarut), pengukuran $\mathrm{pH}$, alkalinitas, titrasi pengendapan (penetapan kadar klorida), titrasi pembentukan senyawa kompleks (penetapan kesadahan air), dan titrasi redoks (penetapan COD)

\section{Pencarian Literatur}

Kegiatan ini dilakukan di luar perkuliahan, dimana mahasiswa mencari literatur baik melalui perpustakaan maupun internet.

\section{Seminar}

Kegiatan seminar proposal ini dimaksudkan agar para mahasiswa melaporkan apa yang diperoleh, berdiskusi dan bertukar pikiran sehingga pelaksanan kerja dalam rangka menjawab permasalahan dapat terlaksana. Dalam seminar ini juga perlu diinformasikan tentang peralatan dan bahan yang tersedia di laboratorium.

\section{Tutorial}

Kegiatan tutorial bertujuan untuk menjawab pertanyaan mahasiswa. Biasanya setelah mahasiswa melakukan seminar akan ditemui hal-hal yang baru yang perlu penjelasan dosen.

\section{Demonstrasi}

Kegiatan ini disampaikan oleh dosen sebelum mahasiswa melakukan eksperimen, terutama dalam hal menggunakan/mengoperasikan alat analisis atau cara pengambilan sampel

\section{Ekperimen}

Eksperimen merupakan kegiatan yang dilakukan mahasiswa untuk mengambil data, menganalisis dan mengintepretasi data. Dalam kegiatan ini mahasiswa juga menulis laporan hasil kerja. Apabila ada data yang tidak sesuai/tidak tepat terhadap solusi permasalahan, maka eksperimen dapat diulang.

\section{Perkuliahan tahap akhir}

Kegiatan perkuliahan tahap akhir berisi tentang laporan hasil kerja kelompok baik secara tertulis maupun lisan. Dalam kegiatan ini seorang dosen membantu merefleksi hasil kerja mahasiswa dan menyimpulkan secara bersamasama.

\section{Sistem Penilaian dalam Pendekatan PBL}

Berbagai model penilaian pada pembelajaran dengan pendekatan PBL telah banyak dilaporkan [1,7,22]. Pada prinsipnya penilaian mencakup kemampuan/ketepatan dalam menyelesaikan masalah dan ketampilan dalam melakukan proses penyelesaian masalah. Dalam artikel ini sistem penilaian disajikan dalam tabel 3.

Tabel 3. Komponen penilaian dalam PBL

\begin{tabular}{|c|c|c|}
\hline & Komponen yang dinilai & Persentase \\
\hline 1. & $\begin{array}{l}\text { Tes tertulis: kebenaran dalam } \\
\text { menjawab permasalahan }\end{array}$ & $30 \%$ \\
\hline 2. & $\begin{array}{l}\text { Laporan tertulis: ketrampilan } \\
\text { berkomunikasi secara tertulis }\end{array}$ & $25 \%$ \\
\hline 3. & $\begin{array}{l}\text { Unjuk kerja: ketrampilan } \\
\text { selama proses penyelesaian } \\
\text { masalah }\end{array}$ & $15 \%$ \\
\hline 4. & $\begin{array}{l}\text { Sikap: perilaku yang } \\
\text { ditunjukkan mahasiswa }\end{array}$ & $15 \%$ \\
\hline & $\begin{array}{l}\text { selama proses penyelesaian } \\
\text { masalah }\end{array}$ & $15 \%$ \\
\hline 5. & $\begin{array}{l}\text { Presentasi lisan: ketrampilan } \\
\text { berkomunikasi secara lisan }\end{array}$ & \\
\hline Total & & $100 \%$ \\
\hline
\end{tabular}

\section{Keterbatasan Pelaksanaan PBL dalam Perkuliahan Kimia Analitik}

Beberapa keterbatasan yang mungkin ditemukan dalam pelaksanaan PBL dalam perkuliahan antara lain, pertama kesulitan merubah cara konvensional yang cenderung lebih sederhana dan waktu yang lebih singkat [14]. Ke dua perlu biaya mahal termasuk ruangan khusus untuk diskusi, laboratorium beserta peralatan dan bahan. Ke tiga diperlukan motivasi dan ketrampilan laboratorium yang tinggi sebab dosen disamping sebagai motivator juga sebagai fasilitator dalam PBL [1,23]. 


\section{KESIMPULAN}

Kesimpulan yang diperoleh dari pengkajian ini adalah: (1) Pendekatan PBL dalam perkuliahan Kimia Analitik cukup diperlukan, karena bidang ilmu ini mengkaji permasalahn nyata, (2) Pendekatan PBL sebaiknya diterapkan di minggu terakhir perkuliahan, (3) model pembelajaran meliputi identifikasi masalah, perkuliahan awal, pencarian literatur, tutorial, demonstrasi, eksperimen, dan diakhiri dengan perkuliahan akhir, (4) Keterbatasan penerapan PBL dalam perkuliahan Kimia Analitik adalah alokasi waktu, laboratorium, dan kemampuan dosen dalam menerapkan metode analisis kimia.

\section{DAFTAR PUSTAKA}

[1] Wenzel, T.J. (1998). Cooperative group learning inundergraduate analytical chemistry. Analytical Chemistry, 70(23), 790A-795A

[2] Tarhan, L., and Acar, B. (2007). Problem based learning in an eleventh grade chemistry class:factors affecting cell potential. Research in Science and Technological Education, 25(3), 351-369.

[3] McDonnell C., O'Connor C. and Seery M.K., (2007). Developing practical chemistry skills by means of studentdriven problem based learning mini-projects, Chem. Educ.Res. Pract., 8, 130-139.

[4] Potter N.M. and Overton, T.L. (2006). Chemistry in Sport - Context-based eLearning in Chemistry. Chem. Educ. Res.Pract., 7, 195-202.

[5] Bodner G.M., (2003). Problem Solving: The difference between what we do and what we tell students to do, University Chemistry Education, 7, 37-45.

[6] Belt, S.T. and Evans, E.H. (2002). A problem based learning approach to analytical and applied chemistry. University Chemistry Education, 6, 65-72.

[7] Yuzhi, W. (2003). Using Problem-Based Learning and Teaching Analytical Chemistry, The China Papers., July,28-33.

[8] Hmelo-Silver, C. E., \& Barrows, H. S. (2006). Goals and strategies of a problem-based learning facilitator. Interdisciplinary Journal of Problem-based Learning, 1. 21-39.

[9] Akınoglu, O., \& Tandogan R. (2007). The effects of problem-based active learning in science education on students' academic achievement, attitude and concept learning. Eurasia J. Math. Sci. Technol. Edu. 3(1): 7181.

[10] Gallagher, S.A., Stephien, W.J., Sher, B.T. \& Workman, D. (1999). Implementing ProblemBased Learning in Science Classrooms. School Science and Mathematics. 95(3), 136146.
[11] Chin, C. \& Chia, L. G. (2004). ProblemBased Learning: Using Students' Questions to Drive Knowledge Construction, Science Education, 88(5), 707-727.

[12] Hmelo-Silver, C. E. (2004). Problembased learning: What and how do students learn?Educational Psychology Review, 16, 235-266.

[13] Salta, K. \& Tzougraki, C. (2004). Attitudes toward chemistry among 11th grade students in high schools in Greece, Science Education, 88(4), 535-547.

[14] Shelton, J. B. \& Smith, R. F. (1998). Problem-based learning in analytical science undergraduate teaching, Research in Science and Technological Education, 16(1), 19-30.

[15] Larive, C. K. (2004). Problem-based learning in the analytical chemistry laboratory course, Analytical and Bioanalytical Chemistry, 380(3), 357-359.

[16] Bahar M., (2003). The effects of motivational styles on group work and discussion-based seminars, Scandinavian Journal of Educational Research, 47, 461473

[17] Savery, J. R., \& Duffy, T. M. (1994). Problem based learning: an instructional model and its constructivist framework, Educational Technology, 35(5), 31-38.

[18] DIKTI. (1991). Kurikulum Pendidikan MIPA dan Ilmu Pengetahuan Alam Program S-1. DIKTI, Jakarta

[19] Wenzel, T.J. (1995). A new approach to undergraduateanalytical chemistry. Analytical Chemistry, 67, 470A-475A.

[20] Hughes, K.D. (1993). Marine microcosm using an aquarium to teach undergraduate analytical chemistry. Analytical Chemistry, 65, 883A-889A.

[21] Belt, S.T. and Evans, E.H. (2002). A problem based learning approach to analytical and applied chemistry. University Chemistry Education, 6, 65-72.

[22] McDonnell C., O'Connor C. and Seery M.K., (2007). Developing practical chemistry skills by means of studentdriven problem based learning mini-projects, Chem. Educ.Res. Pract., 8, 130-139.

[23] Sahin, M. \& Yörek, N. (2009). A comparison of problem based learning and traditional lecture students' expectations and course grades in an introductory physics classroom. Scientific Research and Essays, 4(8), 753-762. 